Vol. XIX No. 2

\title{
Perfumed fungus on Arabis
}

by Dorothea H. Calverley, Dawson Creek, B.C.

There is a virgin prairie hillside near Dawson Creek where every spring the "crocuses" and a tiny lemon-yellow plant appear simultaneously. After five years of searching for this little plant in flower I decided to lift one in a piece of turf for transplanting to the garden. On the way home the car became filled with an exquisite and rather strong scent reminiscent of a very expensive face-powder. The perfume came from the brightyellow leaves of this two-inch plant.

Transplanited, the plant became by autumn rather woody, almost normally green and about the diameter of a tea-plate. It pcrsisted for two years, but did not produce flowers. It was identified as one of the Cruciferae in the genus Arabis by a U.B.C. botanist. The Research Branch of the Department of Agriculture advised me that the Arabis was diseased. The fungus is a rust probably Puccinia monoica (Peck) Arthur which has a wide range. It parasitizes Arabis and one or two other Cruciferae. I found it later on small Drummond's Rack Cress near Taylor, B.C. It does nat occur on Brassica species in
North America. The pycnial (spermagonial) stage of rusts often attracts insects, which can play a similar role in the life history of a rusit as they do in a pollination of higher plants.

One very hot afternoon, in early June, 1960 , I was attracted by a loud buzzing of a bumblebee, which was rolling and tumbling in an apparent ecstacy in and among the yellow leaves. He would fly off ten feet, only to return at once, and once more begin antics much like a cat in a catnip plant. I watched him for over an hour before he disappeared. Careful examination revealed no flowers at all, but the plant was highly scented, even when the leaves were not bruised. As the yellow appearance was a type of fungus, I destroyed the plant before bees could carry it to my rock-garden Cruciferae, or to the rapeseed crops.

For the purpcise of attracting insects, this particular rust seems to have developed a very potent perfume in comparison with which even Chanel \#5 should look to its reputation!

\section{Blue-green Algae in Saskatchewan Lakes}

\section{by U. Theodore Hammer, University of Saskatchewan, Saskatoon}

Teachers and students of high school biology as well as other naturalists may find it very rewarding to devote some time to the study of blue-green algae. These algae are found in most of the well-populated areas of Saskatchewan and are readily collected and easily studied with the aid of a microscope. Considered along with bacteria as very primitive plants, their characteristics are much more easily observed than those of bacteria and without the necessity of staining. In addition, they can be preserved for future use, or, in some cases, easily cultured.

The blue-green algaie are a highly successful group of plants. They occur in extremely diverse habitats and conditions. These algae are found in inter-tidal belts of seas and salt marshes, are widespread terrestrially and are important constituents of free-floating (plankton) flora in all fresh-waters. They may occur in hot springs or under the ice during the winter. Most of them are freeliving; some grow on animals while other grow on or in the tissues of plants. Some members of the group are the algal components in the symbiotic relationship of algae and fungi in lichens. Others even occur as parasites in the digestive tracts of man and other animals.

In Saskatchewan, although they occur extensively in the soil, bluegreens are most readily obtained from lakes. Algal "blooms" (heavy concentrations of algae at or near the surface) occur intermittently in many lakes during the summer and fall. 


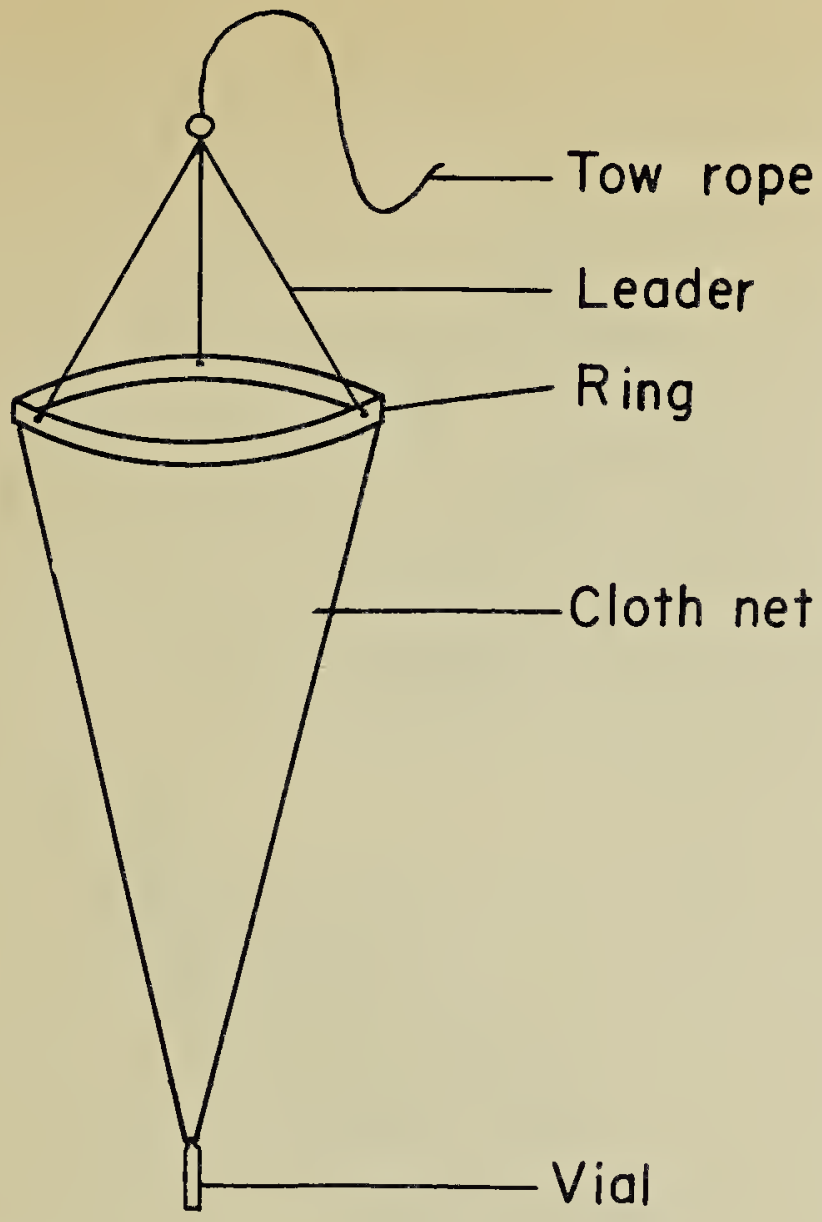

Fig. 1

\section{The Plankton Net}

They are usually most abundant in the well nourished lakes of the prairie region but are occasionally common in lakes as far north as the Canadian Shield. Samples of these blooms may be collected along the shore where they tend to collect due to wind action or in small protected coves. Blooms, usually, tend to be marde up of only a few species. A good sample may be obtained by the use of a fine-meshed cone-shaped net (Figure 1) pulled through the water or by pouring lake water directly through the net. If a tesit tube or vial is tied in the opening in the small end of the cone, the algae will collect in the tube. Nets may be constructed from about a yard of silk bolting cloth from flour mills. Bottom living forms can most easily be obtained by putting some bottom mud in a baittery jar with lake water. A green mat consisting essentially of blue-green algae will soon cover the mud.

Blue-green algae are best observed in the living state. To ensure this the collecting bottle should not be filled more than one-quarter full and the cover should be removed as soon as convenient. Some forms, such as
Microcystis, may be kept up to a year in an ordinary refrigerator. Others, however, soon perish under such treatment If it isn't practical to examine the material within a day or so of collection, it is best to preserve it. $3 \%$ formalin (3cc. commercial formalin in $37 \mathrm{cc}$. of water is a general preservative. Formalin-acetic acid-alcohol (FAA) is the best preservative for plant materials. To 50 c.c. of $95 \%$ alcohol add 5 c.c. of glacial acetic acid, $10 \mathrm{cc}$. commercial formalin, and $35 \mathrm{cc}$. water. The preserving liquid should be used in an amount equal in volume to the volume of the material and its water medium. Cork stoppered boittles are preferable to screw clap bottles.

Blue-green algae are examined readily under the low power objective of a microscope. The material should be applied to the slide in minute quantities and covered with a cover glass. $5 \%$ glycerine may be added to prevent drying out. A high power objective is sufficient to observe mosit of the desired cell detail.

Blue-green algae make up the Class Myxophyceae of the Phylum Cyanophyta in the plant kingdom. They are thought to have existed in Pre-Cambrian times and are considered to be present in fossil form in very ancient strata. They have no true nuclei (that is, no nuclear membranes or nucleoli), no chromartophores and no sexulal reproduction. The pigments are scartered in the cytoplasm and consist mainly of chlorophyll a, B-carotene, phycocyanin (a blue pigment from which they derive their popular name) and phycoerythrin, a red pigment. The colors of these algae vary considerably depending on the proportions of these various pigments present. Reproduction generally occurs by cell division and fragmentation of cell aggregates. In filamentous types spores called akinettes are produced. These akineittes can survive adverse conditions such as dessication and freezing. In some species ordinary cells can withstand severe conditions and then develop into new cells, as akinettes do, when more favorable conditions prevail.

The blue-green algae are arranged in two main groups. One group includes those which are unicellular or form simple colonies of cells. The shape of the colony is flat if the cells divide in two planes or tends to be 

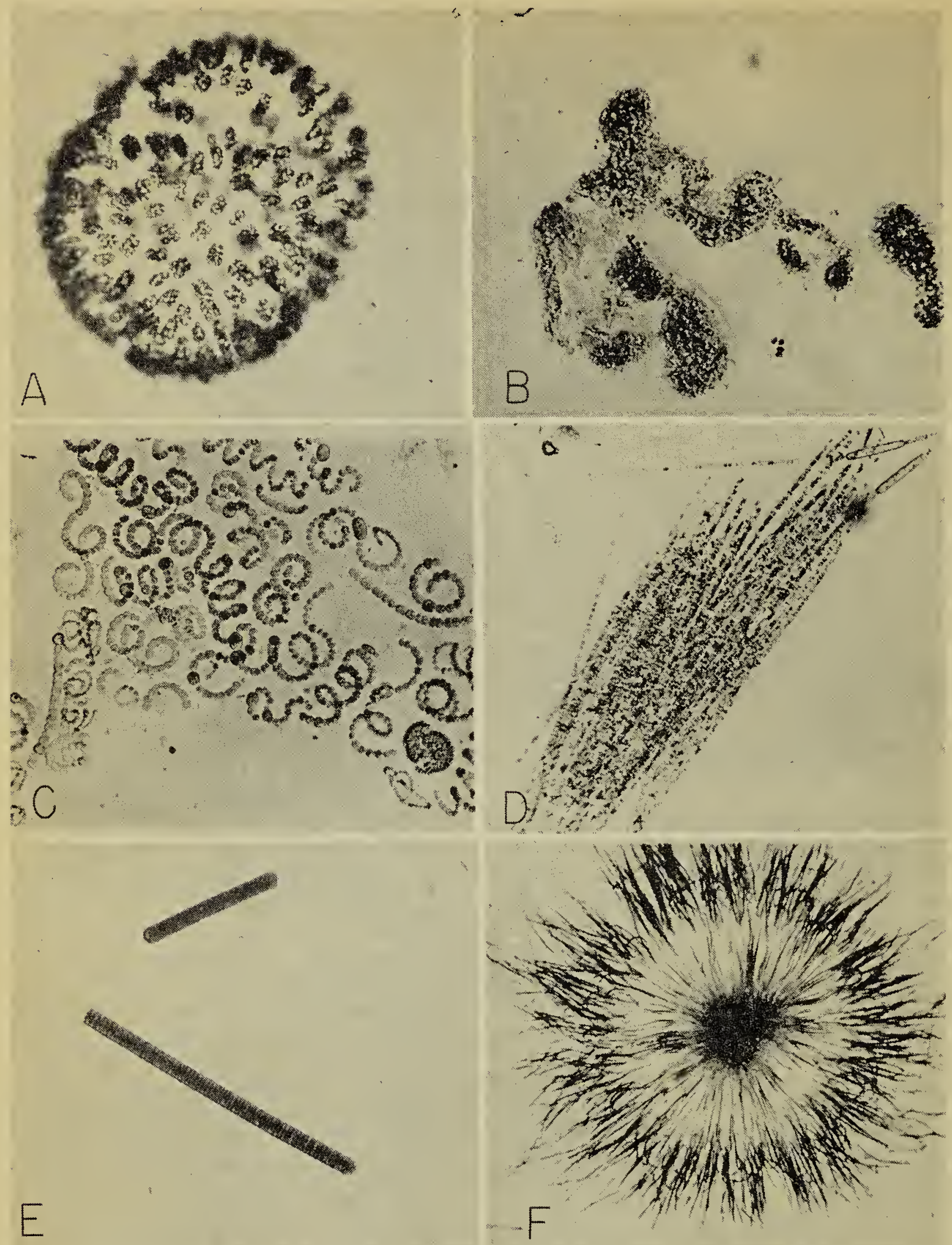

spherical if the cells divide in three planes. The cells are usually held together by a gelatinous matrix. The other group is made up of filamentous species formed by the cells dividing in one plane only. They may be unicellular and may be enclosed in a gelatinous sheath. The filaments may be aggregated to form a colony.

The first group is exemplified by Microcystis, two forms of which are shown in pictures $A$ and $B$, and Coelesphaerium, shown in the lower

right hand corner of photo $C$. This latter photograph, taken of a bloom in Lake Waskesiu, also shows three species of Anabaena, a filamentous genus. The larger cells present in the filaments are akineites. Aphanizomenon is shown in photo D. It consists of filaments accurring in bundles which are readily visible in the water and look like leaf "cuttings". Four akinettes are also visible here. E shows some Lyngbya which formed extensive blooms in 
Humboldt (Stoney) Lake in 1960. F illustrates an example of a colony of Gloeotrichia which consists of filaments extending radially from a mutual centre. To take the photograph the colony was crushed. Oscillatoria, photo $\mathrm{G}$, is a common filamentous form occurring in lakes in the fall. It was abundant under the ice in Wakaw Lake in February, 1961. This genus is also interesting from the sitandpoint of being able to move freely. The movements are of two kinds. One is a horizontal, backand-forth movement while the other involves a terminal waving of the filament.

Blue-green algae have presented several problems. They have a detrimental effect on resiort areas when blooms form and collect in bathing areas. Besides affecting swimming, water skiing and fishing adversely, the decomposition of a bloom may result in obnoxious ador and appearance. Aphanizomenon, Anabaena and Microcystis seem to be the main offenders in this province. Algal toxicity may be associated with blooms. Five different species have been found to be responsible for animal deaths in different parts of the world. Although the five species occur in Saskatchewan only Aphanizomenon, Anabaena flos-aquae and Microcystis occur in sufficient quantities to warrant suspicion here. Cattle, horses, swine, dogs and fowl are all reported to have died after drinking water containing blue-green algae. However, even when these species are present, algal blooms are only infrequently toxic. To test for toxicity, white mice are injected with up to $1 \mathrm{cc}$. of the algal bloom into the abdominal cavity. If toxic it will produce death within a few minutes. In Microcystis the toxin is known to be a polypeptide. No cases of algal poisoning by blue-greens has ever been proved in humans although cases of enteritis (intestinal disorders) sieemis to incriminci.e them.

Water blooms lead iso problems in human water supply as well. They may clog filters and produce tastes that must be removed in water purification plants. Where dense blooms occur the algae may use up the oxygen supply in the water for their own respiration during the night. This oxygen depletion may result in fish kills.

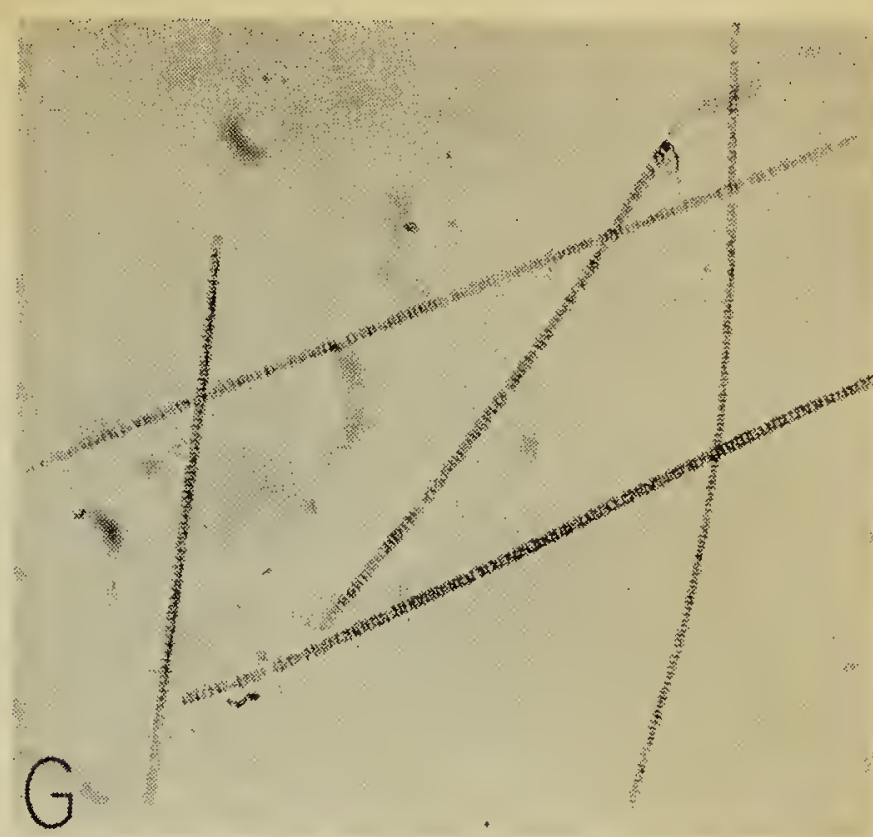

Copper sulphate (and cither chemicals) can be applied to a lake to kill these algae. Although effective, its use is restricted by the high cost of purchase and application of the chemical.

Blue-green algae may be of some practical use. It is well known that some of them, such as some species of Anabaena, fix nitrogen in the form of nitrates. These are then available to other plants which may be important initially in the cycle of life in lakes and ultimately in fish production. This is made use of directly in the growing of rice in Asia. The blue-greens fix nitrogen which is then used by the rice. The algae are then eaten by carp which are utilized as food. Although they are ingested by rough fish in our lakes, it is not known whether they are actually digested by these fish and thus play a part in the food chain.

A knowledge of the Myxophycaea opens up one more segment of the living world, a segment which is filled with a varieity of life forms of interest to the curious.

\section{WEEPING POPLAR}

Mr. B. Weloer of Sedgewick, Alberta, sent in two pictures of trees growing in his pasture. These trees seem similar to typical poplars but they have weeping branches. Since it would be difficult to identify the poplars from the pictures Mr. Weber should send a pressed sample (flowers and fruits as well as leaves) to the Botany Department, University of Alberta, at Edmonton, or to Dr. E. H. Moss, 1110187 Ave., Edmonton. 